KOMITE ETIK PENELITIAN

Nomor: 118/LPPM-STIKES YATSI/VIII/2021

\title{
KETERANGAN LOLOS UJI ETIK
}

ETHICAL APPROVAL

Komite Etik Penelitian STIKes Yatsi Tangerang dalam upaya melindungi hak asasi dan kesejahteraan responden/subyek penelitian, telah mengkaji dengan teliti protokol berjudul:

"Efektivitas Penyuluhan Kesehatan dengan Media Video dan Leaflet terhadap Pengetahuan dan Sikap Pencegahan Stunting pada Anggota Pusat Konseling dan Informasi Remaja (PIKR)"

Peneliti Utama $\quad$ : Bela Novita Amaris Susanto., S.Kep., M.K.M

Nama Institusi $\quad$ : Program Keperawatan STIKes Yatsi Tangerang

Dan telah menyetujui protokol tersebut diatas.

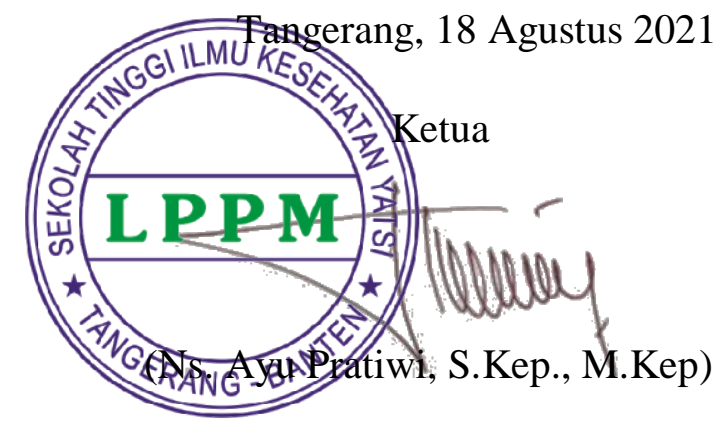

*Peneliti Berkewajiban :

1. Menjaga kerahasiaan identitas subyek penelitian

2. Memberitahu status penelitian apabila :

a. Setelah masa berlakunya keterangan lolos uji etik, penelitan masih belum selesai, dalam hal ini ethical clearance harus diperpanjang

b. penelitian berhenti di tengah jalan

3. Melaporkan kejadian serius yang tidak diinginkan 